Variability of fatty acid profiles, oxidative stability and nutritive quality of oil in selected soybean genotypes

Varijabilnost sadržaja masnih kiselina, oksidacijska stabilnost i nutritivna kakvoća ulja u odabranim genotipovima soje

Matoša Kočar, M., Vila, S., Petrović, S., Rebekić, A., Sudarić, A., Duvnjak, T., Markulj Kulundžić, A.

Poljoprivreda/Agriculture

ISSN: 1848-8080 (Online)

ISSN: 1330-7142 (Print)

https://doi.org/10.18047/poljo.26.2.2

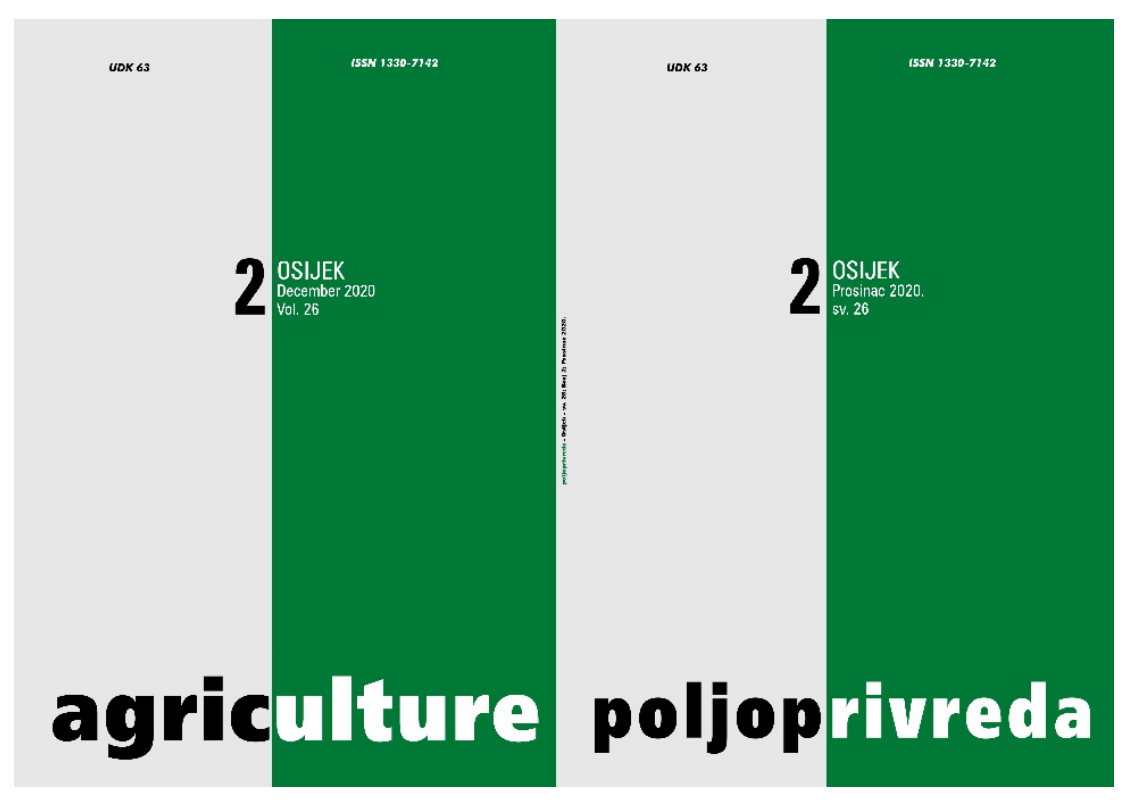

Fakultet agrobiotehničkih znanosti Osijek, Poljoprivredni institut Osijek

Faculty of Agrobiotechnical Sciences Osijek, Agricultural Institute Osijek 
ISSN 1330-7142

$U D K=633.34: 631.527$

https://doi.org/10.18047/poljo.26.2.2

\section{VARIABILITY OF FATTY ACID PROFILES, OXIDATIVE STABILITY AND NUTRITIVE QUALITY OF OIL IN SELECTED SOYBEAN GENOTYPES}

Matoša Kočar, M. (1), Vila, S. ${ }^{(2)}$, Petrović, S. ${ }^{(2)}$, Rebekić, A. ${ }^{(2)}$, Sudarić, A. ${ }^{(1,3)}$, Duvnjak, T. ${ }^{(1)}$, Markulj Kulundžić, A. ${ }^{(1)}$

\section{SUMMARY}

The purpose of this study (2010-12) was to investigate the fatty acid profiles (palmitic - PA, stearic - SA, oleic - OA, linoleic - LA, linolenic - LNA, saturated fatty acids - SFA, monounsaturated fatty acids - MUFA, polyunsaturated fatty acids - PUFA), oxidative stability (MUFA/PUFA, OA/LA), and nutritive quality (LA/LNA) of oil produced by 13 early soybean genotypes created at the Agricultural Institute Osijek, Croatia. The analysis of variance determined significant effect of genotype (G), year (Y), and GXY interaction on all examined traits. The correlation analysis indicated the most important positive correlation existed between the SA and OA, SA and LNA, and LA and LNA, and the most important negative relationship between $O A$ and $L A$, and $O A$ and $L N A$. The principal component analysis yielded four significant principal components (PCs) with the eigenvalues $>1$, which together accounted for $57.84 \%$ of the total variability in the data set. The Eigen analysis of the correlation matrix loadings indicated MUFA/PUFA, MUFA, OA/LA, and OA mostly contribute to the PC1 axis and are in a positive correlation with it, while PUFA, LA, and LNA mostly contribute to a negative direction. These results will facilitate the planning of future breeding programs, aimed at adjusting the fatty acid profiles according to the needs of the processing industry and end consumers.

Keywords: fatty acid profile, nutritive quality, oil, oxidative stability, soybean, PCA

\section{INTRODUCTION}

A nutritional value, stability, and taste of the soybean oil depend on its fatty acid content. Fatty acids can be saturated (myristic - MA, palmitic $P A$, stearic - SA, arachidic - $A A$, behenic - BA and lignoceric acid - LGA), monounsaturated (oleic - OA and erucic acid - EA) or polyunsaturated (linoleic - LA and linolenic acid - LNA). The saturated fatty acids (SFAs), except the SA, are considered to raise cholesterol and increase the risk of a coronary heart disease (Crupkin and Zambelli, 2008; Baum et al., 2012). The most abundant monounsaturated fatty acid (MUFA), the $O A$ is a precursor of some essential fatty acids (EFAs) (Johnson and Saikia, 2009), while the polyunsaturated fatty acids (PUFA) are considered the EFAs. The PUFAs support the cardiovascular, reproductive, immune and nervous systems and are crucial for creating and repairing the cell membranes (Johnson and Saikia, 2009). Furthermore, a LA and LNA ratio (LA/ LNA) can be used to assess a nutritional quality of the soybean oil. According to Scollan et al. (2006), this ratio should be $<4$, as a very high LA/LNA is considered detrimental for human health, so to prevent the degenerative pathologies, the LA needs to be lowered by breeding (Williams et al., 2011). As health benefits

(1) Maja Matoša Kočar, Ph. D. (maja.matosa@poljinos.hr), Aleksandra Sudarić, Ph. D., Tomislav Duvnjak, Ph. D., Antonela Markulj Kulundžić, Ph. D. - Agricultural Institute Osijek, Južno predgrađe 17, 31000 Osijek, Croatia, (2) Prof. Dr. Sonja Vila, Assoc. Prof. Sonja Petrović, Assoc. Prof. Andrijana Rebekić - Josip Juraj Strossmayer of Osijek, Faculty of Agrobiotechnical Sciences Osijek, Vladimira Preloga 1, 31000 Osijek, Croatia, (3) Center of Excellence for Biodiversity and Molecular Plant Breeding, University of Zagreb, Faculty of Agriculture, Svetošimunska cesta 25, 10000 Zagreb, Croatia 
increase with an increase in the degree of fatty acid unsaturation, an oxidative stability of oil decreases (Duh et al., 1999). A poor oxidative stability prevents the use of oil at high cooking temperatures, reduces the shelf-life, and causes off-flavors (Lee et al., 2007). An oxidative stability of the soybean oil, determined by a MUFA and PUFA ratio (MUFA/PUFA) (Rani et al., 2007), can be improved by a trans-isomer producing catalytic hydrogenation or by breeding for a higher $\mathrm{OA}$ content (Wilson, 2004; Lee et al., 2007; Rani et al., 2007). The diets rich in trans-fatty acids increase the risk of cardiovascular diseases (Brouwer et al., 2010), so increasing the $O A$ is considered a better option. An $O A$ and $L A$ ratio $(O A / L A)$ can be used as a quality index for assessing the shelf-life and the oil's health benefits (Shin et al., 2012). For example, a high OA/LA ratio $(\geq 10: 1)$ in peanut increases the shelf life for up to 10 times and improves the flavor, when compared to a normal $0 A / L A$ ratio $(\sim 1.5: 1)$ (Chamberlin et al., 2011). The main fatty acids in the soybean oil are PA (C16:0), SA (C18:0), OA (C18:1), LA (C18:2) and LNA (C18:3), while others (MA, AA, BA, EA) are present in traces. In general, a commodity soybean oil contains $13 \%$ of PAs, $4 \%$ of SAs, $20 \%$ of $0 A s, 55 \%$ of LAs and $8 \%$ of LNAs (Fehr, 2007), but the most profitable fatty acid phenotypes are those which produce a universalquality oil that can be used for food, feed, and industry, with an SFA reduced to less than 7\%, LNA reduced to less than $3 \%$, and $0 A$ increased to more than $55 \%$ (Wilson, 2004).

Although the European countries import $95 \%$ of an annual soybeen seed demand, meal, and oil from the overseas countries, causing an enormous trade deficit (Dima, 2016; Kurasch et al., 2017), the harvested area in Europe has been continuously increasing over the past few years (FAOSTAT, 2020). The majority of soybean in the European Union (EU) is used as poultry and pork feed (Pascal and Rodriguez Cerezo, 2015), but using soybean seed as a stock for oil production would diversify oilseed crops and stabilize the otherwise volatile oilseed market by partially offsetting the economic effects of the adverse weather conditions. Furthermore, as the European consumers are becoming increasingly concerned with the dietary values and functional properties of the oil and prefer the GM-free oilseed end products (Hemingway et al., 2015), producing the high-quality oil phenotypes by the conventional breeding methods should be high on a priority list for the European soybean breeders. The aim of this study was determining a genetic variability of the fatty acid profiles, i.e., a germplasm characterization as a prerequisite for the germplasm conservation and utilization, as well as for a successful crop improvement.

\section{MATERIAL AND METHODS}

\section{Field trial}

A triennial field trial (2010-12), investigating 13 early soybean (Glycine max (L.) Merr.) genotypes
(Table 1), was set up at the Agricultural Institute

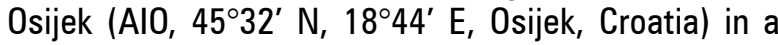
randomized complete block design with four replicates. All chosen genotypes were developed and are owned by the AIO. The experimental plot size was $10 \mathrm{~m}^{2}$, a distance between the rows amounted to $50 \mathrm{~cm}$, and a seed distance within a row amounted to $2-3 \mathrm{~cm}$. During the field trial, all currently accepted agricultural management practices were applied, and the trial plots were harvested each year at a full harvesting maturity (R8) (Fehr et al., 1971), after which the soybean seed samples were taken for the sake of the fatty acid analyses.

\section{Laboratory analyses}

The oil for fatty acid analysis was extracted using the Soxhlet apparatus (Sigma-Aldrich, Germany) with the diethyl ether (J.T. Baker, Netherlands), containing butylhydroxytoluene as an inhibitor (Carlo Erba Reagents, Italy). The preparation of fatty acid methyl esters was carried out according to the ISO 5509:2000 standard (boron trifluoride method). The fatty acid methyl esters were analyzed using the gas chromatography system GC-2010 Plus (Shimadzu, Japan) equipped with a flame ionization detector (FID). The separation was performed on a Forte GC (Shimadzu) column (length $30 \mathrm{~m}$, inner diameter $0.25 \mathrm{~mm}$, film thickness $0.25 \mu \mathrm{m}$ ). The injected sample volume was $1 \mu \mathrm{l}$, and the operating conditions were as follows: an inlet temperature set at $225^{\circ} \mathrm{C}$, a detector temperature set at $250^{\circ} \mathrm{C}$, and He as a carrier gas (Vodovod Osijek, Croatia) at a flow rate of $1.24 \mathrm{ml} \mathrm{min}^{-1}$. The initial oven temperature of $150^{\circ} \mathrm{C}$ was held for seven mins., when it was increased to $240^{\circ} \mathrm{C}$ (held for $1 \mathrm{~min}$.) at a rate of $8^{\circ} \mathrm{C} \mathrm{min}-1$, and finally increased to $250^{\circ} \mathrm{C}$ and held for 5 mins. The fatty acids were separated according to the number of carbon atoms and the number of double bonds. The fatty acids were identified by comparing the measured retention time to the AOCS standard FAME \#3 (Restek, USA) and quantified using the method of normalization based on a peak area. The Fatty acid analysis quantified 10 fatty acids: MA, PA, SA, OA, LA, LNA, AA, BA, EA, and LGA.

\section{Experimental site weather conditions}

The average monthly air temperatures $\left({ }^{\circ} \mathrm{C}\right)$ and the distribution of total monthly precipitation amount $(\mathrm{mm})$ for the soybean growing season (April - September) in years 2010-12, along with the respective long-term averages (LTA) (1961-90) at the location Osijek, Croatia, are presented in Figure 1. All three years differed in terms of weather conditions, with the average monthly temperatures higher than the LTA in all three experimental years (Fig. 1a). Furthermore, the conditions in 2010 were much more humid during the soybean growing season than in 2011 and 2012, with more precipitation than the LTA, while 2011 and 2012 were below the precipitation LTA (Fig. 1b). 
a)

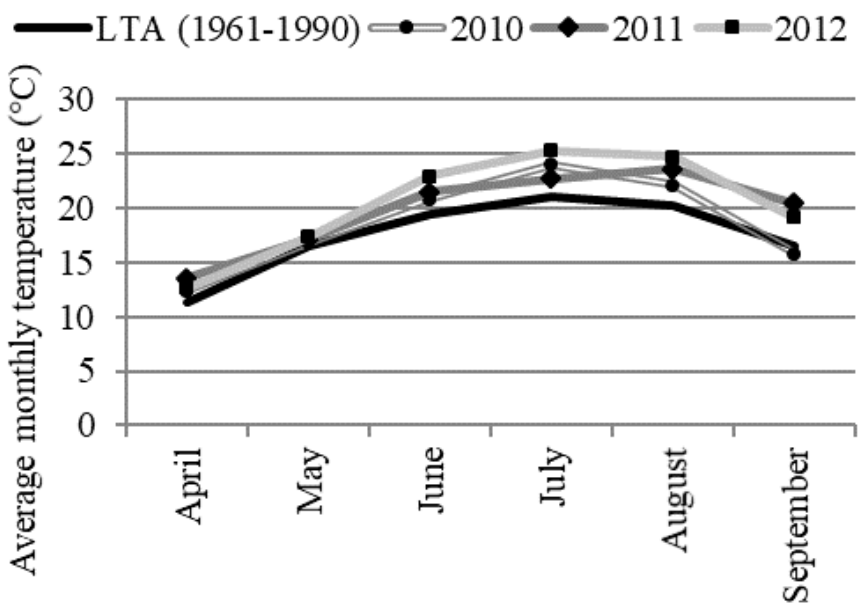

b)
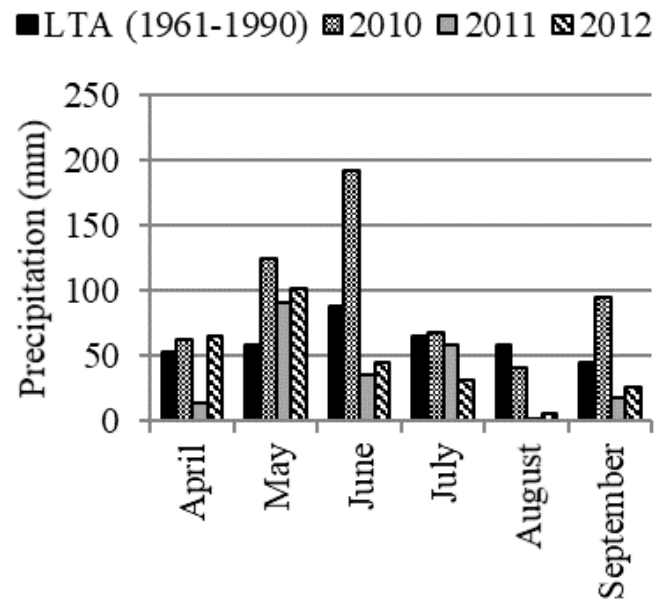

Figure 1. The long-term average (LTA) monthly temperatures and average monthly temperatures $\left({ }^{\circ} \mathrm{C}\right)(\mathrm{a})$, total monthly precipitation LTA, and total monthly precipitation $(\mathrm{mm})(\mathrm{b})$ in the years 2010-12 for a soybean growing season (April - September) in Osijek, Croatia (Croatian Meteorological and Hydrological Service)

Slika 1. Prosječne mjesečne temperature ( $\left.{ }^{\circ} \mathrm{C}\right)$ za višegodišnje razdoblje (LTA) te godine 2010. - 2012. za vrijeme vegetacije soje (travanj - rujan) u Osijeku, Hrvatska; b) Prosječne ukupne mjesečne oborine za višegodišnje razdoblje (1961. - 1990.) te godine 2010. - 2012. za vrijeme vegetacije soje (travanj - rujan) u Osijeku, Hrvatska (Državni hidrometeorološki zavod)

\section{Statistical analyses}

The values of the PA, SA, OA, LA and LNA contents were presented and statistically analyzed individually. SFA content combined the contents of MA, PA, SA, $A A, B A$ and LGA, a MUFA content combined the contents of $O A$ and $E A$, and the PUFA content combined the contents of LA and LNA. The sources of variation were determined by an analysis of variance (ANOVA) followed by Fisher's least significant difference test (LSD test) at a $99 \%$ confidence level to determine the differences between the average values of examined traits. The relationships among the investigated traits were determined by the Pearson correlation coefficient at a $99 \%$ confidence level. The PCA results were visually presented by a biplot, which mapped the genotypes and variables through dimensional spaces determined by principal components (PCs) with eigenvalues greater than 1.0, according to Kaiser's rule (Kaiser, 1960). All analyses were conducted using the Statistica 12.0 (StatSoft Inc., USA, 2013) software.

\section{RESULTS AND DISCUSSION}

The average fatty acid contents (Table 1 ) in 13 genotypes investigated in this study were similar to the values most common for fatty acid contents in commodity soybean (Fehr, 2007) and the values determined in many studies with different sets of soybean germplasm
(Chen, 1995; Rani et al., 2007; Fan et al., 2015; Priolli et al., 2019; Abdelghany et al., 2020). The tested material exhibited significant phenotypic variability for the mentioned traits. The coefficient of variation (CV, \%) was the highest for the SA (20.23\%) and the lowest for the PA (4.88\%) (Tables 1 and 2). In 663 soybean accessions originating from four diverse germplasm collections, Abdelghany et al. (2020) determined the highest CV for the LNA $(15.34 \%)$ and the lowest one for the LA $(5.07 \%)$. If we considered other important soybean seed quality traits, such as protein and oil content (Bueno et al., 2013; Ghodrati et al., 2013), fatty acids exhibit the much higher CV values in general, indicating that there is a room for progress in breeding concerning the favorable fatty acid profiles, depending on the needs of the processing industry and consumers. On the other hand, fatty acids with the lower CVs, such as the PA $(4.88 \%)$, LA $(5.11 \%)$, and PUFA $(5.93 \%)$, are much more stable across the genotypes and environments, and are thus more predictable. The calculated ratios provide even more information on the value of the soybean oil (Tables 1 and 2). If we consider that the optimal MUFA/PUFA ratio is $>0.5$ for soybean (Rani et al., 2007), the average value of 0.43 would indicate a poor oxidative stability. The average $0 \mathrm{~A} / \mathrm{LA}$ value of 0.48 further corroborates the claim that the soybean oil, although rich in the essential omega- 6 fatty acid, has a low oxidative stability. The average LA/LNA value of 
7.92 suggests that these soybeans have to be combined with other foods rich in the LNA (Ivanov, 2010) to satisfy the nutritional quality needs. Nevertheless, the relatively high CV values for these traits (Table 2) indicate there is a room for progress. A phenotypic variability for all the tested traits was confirmed with the ANOVA, indicating the significance $(p \leq 0.01)$ of genotype $(G)$, year $(Y)$, and the $G x Y$ as the sources of variation for all the tested traits (Table 3 ), which coincides with the results of Bellaloui et al. (2015), Fan et al. (2015), and Mourtzinis et al. (2017). The maximum average $\mathrm{PA}, \mathrm{SA}$, and $\mathrm{OA}$ contents and the minimum average LA and LNA contents were determined in the hot and dry year 2012, while the highly humid year 2010, with the modest average temperatures during the soybean vegetation (Fig. 1) resulted in the minimum average $S A$ and $O A$ contents and the maximum average LA and LNA contents (Table 1). This was in agreement with the findings of Bellaloui et al. (2015), who reported that the cooler temperatures increase the LNA, while the $\mathrm{OA}$ content is simultaneously negatively affected as a result of an inverse relationship between them. Furthermore, Xue et al. (2008) noticed that an increase in the air temperature during the pod fill significantly favored the synthesis of $O A$, while it was significantly decreasing the LA and LNA.

Table 1. The average fatty acid contents for 13 early soybean genotypes and three research years (2010-12)

Tablica 1. Prosječni sadržaj masnih kiselina (\%) u 13 ranih genotipova soje i tri godine istraživanja (2010. - 2012.)

\begin{tabular}{|c|c|c|c|c|c|}
\hline \multirow{2}{*}{$\begin{array}{l}\text { Genotype / Year } \\
\text { Genotip / Godina }\end{array}$} & \multicolumn{5}{|c|}{$\begin{array}{c}\text { Average fatty acid contents (\%) } \\
\text { Prosječan sadržaj masnih kiselina (\%) }\end{array}$} \\
\hline & PA & SA & $\mathbf{O A}$ & LA & LNA \\
\hline OS-L-453 & $10.92^{b} \pm 0.29$ & $4.34^{i} \pm 0.25$ & $24.54^{\dagger} \pm 0.86$ & $52.27^{\text {cde }} \pm 0.69$ & $6.94^{\mathrm{e}} \pm 0.47$ \\
\hline OS-L-513 & $10.69^{f} \pm 0.19$ & $5.52^{c} \pm 0.92$ & $25.11^{\mathrm{d}} \pm 2.09$ & $51.39^{f g} \pm 2.33$ & $6.24^{i} \pm 0.86$ \\
\hline OS-L-526 & $9.94^{k} \pm 0.23$ & $4.70^{h} \pm 0.23$ & $22.42^{k} \pm 1.08$ & $53.93^{b} \pm 1.06$ & $7.59^{\mathrm{a}} \pm 0.46$ \\
\hline OS-L-554 & $10.73^{\mathrm{e}} \pm 0.19$ & $5.79^{b} \pm 1.02$ & $25.45^{\mathrm{c}} \pm 2.18$ & $50.71^{\mathrm{h}} \pm 2.49$ & $6.19^{i} \pm 0.78$ \\
\hline OS-L-581 & $10.79^{d} \pm 0.24$ & $4.41^{i} \pm 0.65$ & $25.08^{d} \pm 1.01$ & $51.44^{f} \pm 1.18$ & $7.10^{c} \pm 0.59$ \\
\hline OS-L-711 & $9.31^{\prime} \pm 0.17$ & $3.86^{\mathrm{i}} \pm 0.43$ & $27.38^{\mathrm{a}} \pm 3.22$ & $52.00^{\mathrm{e}} \pm 2.45$ & $6.22^{i} \pm 1.14$ \\
\hline OS-L-712 & $11.06^{\mathrm{a}} \pm 0.12$ & $3.73^{\mathrm{j}} \pm 0.35$ & $23.92^{\mathrm{hi}} \pm 2.72$ & $54.32^{\mathrm{a}} \pm 2.26$ & $5.77^{\mathrm{j}} \pm 1.01$ \\
\hline OS-L-821 & $10.57^{9} \pm 0.29$ & $5.34^{\mathrm{d}} \pm 0.89$ & $23.54^{j} \pm 3.18$ & $52.22^{\mathrm{de}} \pm 2.97$ & $7.17^{\mathrm{b}} \pm 1.44$ \\
\hline OS-L-442 & $10.53^{h} \pm 0.13$ & $5.03^{\mathrm{ef}} \pm 0.98$ & $23.82^{i} \pm 3.23$ & $52.49^{c d} \pm 3.17$ & $7.05^{d} \pm 0.94$ \\
\hline OS-L-874 & $10.85^{\mathrm{c}} \pm 0.06$ & $5.08^{e} \pm 0.79$ & $24.36^{9} \pm 2.73$ & $51.09^{9} \pm 3.26$ & $6.60^{f} \pm 1.04$ \\
\hline OS-L-875 & $10.48^{i} \pm 0.29$ & $5.31^{d} \pm 0.80$ & $24.83^{\mathrm{e}} \pm 2.78$ & $51.09^{9} \pm 3.08$ & $6.49^{g} \pm 0.99$ \\
\hline OS-L-877 & $10.26^{\mathrm{j}} \pm 0.18$ & $4.91^{\mathrm{fg}} \pm 0,79$ & $24.05^{\mathrm{h}} \pm 3.22$ & $52.58^{\mathrm{c}} \pm 2.49$ & $6.93^{\mathrm{e}} \pm 1.24$ \\
\hline OS-L-899 & $10.47^{i} \pm 0.57$ & $6.03^{\mathrm{a}} \pm 1.08$ & $25.77^{b} \pm 2.59$ & $50.17^{i} \pm 2.72$ & $6.35^{\mathrm{h}} \pm 0.73$ \\
\hline 2010 & $10.53^{B} \pm 0.48$ & $4.17^{C} \pm 0.41$ & $22.02^{\mathrm{C}} \pm 1.72$ & $54.66^{\mathrm{A}} \pm 1.16$ & $7.56^{\mathrm{A}} \pm 0.58$ \\
\hline 2011 & $10.39^{C} \pm 0.50$ & $4.89^{\mathrm{B}} \pm 0.79$ & $24.75^{\mathrm{B}} \pm 1.44$ & $51.48^{\mathrm{B}} \pm 2.21$ & $6.93^{\mathrm{B}} \pm 0.51$ \\
\hline 2012 & $10.59^{\mathrm{A}} \pm 0.54$ & $5.73^{\mathrm{A}} \pm 0.99$ & $27.14^{\mathrm{A}} \pm 1.89$ & $49.79^{C} \pm 1.68$ & $5.62^{C} \pm 0.68$ \\
\hline Average / Prosjek & $10.51 \pm 0.51$ & $4.93 \pm 0.99$ & $24.64 \pm 2.69$ & $51.98 \pm 2.66$ & $6.67 \pm 1.03$ \\
\hline $\mathbf{L S D}_{0.01} / L S D_{0,01}$ & 0.026 & 0.162 & 0.157 & 0.342 & 0.057 \\
\hline CV (\%) & 4.88 & 20.23 & 10.92 & 5.11 & 15.51 \\
\hline
\end{tabular}

PA - palmitic acid - palmitinska kiselina; SA - stearic acid - stearinska kiselina; OA - oleic acid - oleinska kiselina; LA - linoleic acid - linolna kiselina; LNA - linolenic acid - linolenska kiselina; Genotype and year averages with the same letter in superscript are not significantly different at $\mathrm{p} \leq 0.01-$ Prosjeci genotipa i godina s istim slovima u superskriptu nisu statistički različiti kod $P=0,01$ 
Table 2. The triennial (2010-12) average fatty acid contents and ratios in 13 early soybean genotypes Tablica 2. Trogodišnji (2010. - 2012.) prosječni sadržaj masnih kiselina i omjeri u 13 ranih genotipova soje

\begin{tabular}{|c|c|c|c|c|c|c|}
\hline & SFA & MUFA & PUFA & MUFA/PUFA & OA/LA & LA/LNA \\
\hline OS-L-453 & $16.32^{\mathrm{ef}} \pm 0.48$ & $24.64^{f} \pm 0.88$ & $59.20^{d} \pm 1.11$ & $0.42^{f} \pm 0.02$ & $0.47^{f} \pm 0.02$ & $7.08^{g} \pm 0.46$ \\
\hline OS-L-513 & $17.22^{b c} \pm 1.06$ & $25.13^{d} \pm 2.08$ & $57.64^{9} \pm 3.05$ & $0.44^{\mathrm{d}} \pm 0.06$ & $0.49^{d} \pm 0.06$ & $8.35^{c} \pm 0.99$ \\
\hline OS-L-526 & $15.96^{\mathrm{ef}} \pm 0.11$ & $22.51^{\mathrm{k}} \pm 1.06$ & $61.52^{\mathrm{a}} \pm 1.08$ & $0.37^{i} \pm 0.02$ & $0.42^{j} \pm 0.03$ & $7.12^{i} \pm 0.49$ \\
\hline OS-L-554 & $17.61^{\mathrm{abc}} \pm 1.11$ & $25.49^{c} \pm 2.16$ & $56.91^{\mathrm{h}} \pm 3.21$ & $0.45^{c} \pm 0.06$ & $0.51^{c} \pm 0.07$ & $8.27^{c} \pm 0.76$ \\
\hline OS-L-581 & $16.34^{\mathrm{ef}} \pm 0.95$ & $25.11^{d} \pm 1.02$ & $58.55^{\mathrm{e}} \pm 1.78$ & $0.43^{\mathrm{e}} \pm 0.03$ & $0.49^{d} \pm 0.03$ & $7.28^{\mathrm{h}} \pm 0.47$ \\
\hline OS-L-711 & $14.32^{\mathrm{g}} \pm 0.48$ & $27.46^{\mathrm{a}} \pm 3.22$ & $58.22^{f} \pm 3.58$ & $0.48^{\mathrm{a}} \pm 0.09$ & $0.53^{a} \pm 0.09$ & $8.59^{\mathrm{b}} \pm 1,34$ \\
\hline OS-L-712 & $15.92^{f} \pm 0.54$ & $23.99^{h i} \pm 2.71$ & $60.09^{\mathrm{b}} \pm 3.26$ & $0.40^{i} \pm 0.07$ & $0.44^{i} \pm 0.07$ & $9.65^{a} \pm 1.48$ \\
\hline OS-L-821 & $17.02^{\mathrm{cd}} \pm 1.20$ & $23.57^{i} \pm 3.16$ & $59.39^{d} \pm 4.33$ & $0.40^{i} \pm 0.08$ & $0.46^{\mathrm{h}} \pm 0.08$ & $7.50^{g} \pm 1.26$ \\
\hline OS-L-442 & $16.55^{\mathrm{de}} \pm 0.93$ & $23.87^{i} \pm 3.20$ & $59.54^{\mathrm{c}} \pm 4.11$ & $0.41^{\mathrm{h}} \pm 0.08$ & $0.46^{g h} \pm 0.09$ & $7.52^{9} \pm 0.58$ \\
\hline OS-L-874 & $17.88^{\mathrm{a}} \pm 1.96$ & $24.48^{9} \pm 2.79$ & $57.70^{9} \pm 4.09$ & $0.43^{e} \pm 0.08$ & $0.48^{\mathrm{e}} \pm 0.08$ & $7.86^{e} \pm 0.97$ \\
\hline OS-L-875 & $17.81^{\mathrm{ab}} \pm 1.84$ & $24.92^{\mathrm{e}} \pm 2.78$ & $57.59^{9} \pm 3.84$ & $0.44^{d} \pm 0.07$ & $0.49^{d} \pm 0.08$ & $7.99^{\mathrm{d}} \pm 1.04$ \\
\hline OS-L-877 & $16.15^{\mathrm{ef}} \pm 0.68$ & $24.11^{\mathrm{h}} \pm 3.21$ & $59.51^{c d} \pm 4.18$ & $0.41^{g} \pm 0.08$ & $0.46^{9} \pm 0.09$ & $7.76^{f} \pm 1.02$ \\
\hline OS-L-899 & $17.67^{\mathrm{ab}} \pm 1.14$ & $25.81^{b} \pm 2.56$ & $56.52^{i} \pm 3.43$ & $0.46^{b} \pm 0.07$ & $0.52^{b} \pm 0.08$ & $7.95^{\mathrm{de}} \pm 0.51$ \\
\hline Average & $16.68 \pm 1.43$ & $24.70 \pm 2.68$ & $58.65 \pm 3.48$ & 0.43 & $0.48 \pm 0.08$ & $7.92 \pm 1.11$ \\
\hline $\operatorname{LSD}_{0.01}$ & 0.606 & 0.143 & 0.317 & 0.003 & 0.004 & 0.103 \\
\hline CV (\%) & 8.55 & 10.86 & 5.93 & 16.55 & 15.59 & 14.15 \\
\hline
\end{tabular}

SFA - saturated fatty acids - zasićene masne kiseline; MUFA - monounsaturated fatty acids - mononezasićene masne kiseline; PUFA - polyunsaturated fatty acids - polinezasićene masne kiseline; MUFA/PUFA - monounsaturated and polyunsaturated fatty acid ratio - omjer mono- $i$ polinezasićenih kiselina; OA/LA - oleic and linoleic acid ratio - omjer oleinske $i$ linolne kiseline; LA/LNA - linoleic and linolenic acid ratio - omjer linolne i linolenske kiseline; Genotype averages with the same letter in superscript are not significantly different at $\mathrm{p} \leq 0.01-$ Prosjeci genotipova $s$ istim slovima u superskriptu nisu statistički različiti kod $P=0,01$

Table 3. ANOVA (mean squares and significance) for the tested traits in 13 early soybean genotypes (0sijek, Croatia, 2010-12)

Tablica 3. ANOVA (sredina kvadrata i značajnost) za testirana svojstva kod 13 ranih genotipova soje (Osijek, Hrvatska, 2010. - 2012.)

\begin{tabular}{|c|c|c|c|c|c|c|}
\hline \multirow{2}{*}{$\begin{array}{l}\text { Source of variation } \\
\text { Izvor varijabilnosti }\end{array}$} & \multicolumn{6}{|c|}{ Fatty acids / Masne kiseline } \\
\hline & \multicolumn{2}{|c|}{ PA } & SA & $\mathbf{O A}$ & LA & LNA \\
\hline Genotype (G) / Genotip (G) & \multicolumn{2}{|c|}{$2.59^{* *}$} & $5.90^{* *}$ & $17.67^{* *}$ & $17.12^{* *}$ & $3.15^{* *}$ \\
\hline Year (Y) / Godina (Y) & \multicolumn{2}{|c|}{$0.59^{* *}$} & $31.79^{* *}$ & $341.72^{* *}$ & $316.33^{* *}$ & $55.48^{* *}$ \\
\hline GxY & \multicolumn{2}{|c|}{$0.35^{* *}$} & $0.69^{* *}$ & $9.27^{* *}$ & $10.18^{* *}$ & $0.66^{* *}$ \\
\hline Source of variation & \multicolumn{3}{|c|}{ Fatty acids / Masne kiseline } & \multicolumn{3}{|c|}{ Ratios / Omjeri } \\
\hline Izvor varijabilnosti & SFA & MUFA & PUFA & MUFA/PUFA & OA/LA & LA/LNA \\
\hline Genotype (G) / Genotip (G) & $42.29^{* *}$ & $338.74^{* *}$ & $617.72^{* *}$ & $0.25^{* *}$ & $0.27^{* *}$ & $48.08^{* *}$ \\
\hline Year (Y) / Godina (Y) & $12.21^{* *}$ & $17.52^{* *}$ & $23.54^{* *}$ & $0.01^{* *}$ & $0.01^{* *}$ & $5.88^{* *}$ \\
\hline GxY & $1.93^{* *}$ & $9.43^{* *}$ & $14.53^{* *}$ & $0.01^{* *}$ & $0.01^{* *}$ & $1.11^{* *}$ \\
\hline
\end{tabular}

PA - palmitic acid - palmitinska kiselina; SA - stearic acid - stearinska kiselina; OA - oleic acid - oleinska kiselina; LA - linoleic acid - linolna kiselina; LNA linolenic acid - linolenska kiselina; SFA - saturated fatty acids - zasićene masne kiseline; MUFA - monounsaturated fatty acids - mononezasićene masne kiseline; PUFA - polyunsaturated fatty acids - polinezasićene masne kiseline; ${ }^{* *} \mathrm{p} \leq 0.01$

A correlation and regression analysis (Table 4) between the tested traits revealed a strong, positive, and significant relationship between the $\mathrm{SA}$ and $\mathrm{OA}$ and LA and the LNA, a strong, negative, and significant between the SA and the LNA, and a very strong, negative, and significant between the $O A$ and $L A$ and the $O A$ and LNA. In a soybean study by Shin et al. (2012), the only two significant correlations were a very strong and negative one between the $O A$ and $L A$ and a mediumstrong and negative one between the OA and LNA, while in a peanut study (Shin et al., 2010) the OA and $L A$ and the $O A$ and PA were in a very strong negative relationship, while the PA and LA were in a very strong positive relation. A well-documented and very strong 
correlation between the $\mathrm{OA}$ and the LA originates from the biochemical pathways of fatty acid synthesis in both the soybean and peanut, and is therefore expected and taken into consideration during selection. Other relationships among different traits can be seen in the biplot (Fig. 2), where the variables which form an acute angle with the origin of the coordinate plane are in a positive correlation, those that form an obtuse angle are in a mutually negative relationship, while the right angles indicate no correlation (Murphy et al., 2009). Knowing the strength and direction of significant correlations enables an indirect selection of important agronomic traits and thus is of a great value for the breeding programs. In this case, as in some previous studies (Kumar et al., 2004; Rani et al., 2007), a very strong and negative correlation between the $O A$, which increases an oxidative stability, and the LA and LNA, which both decrease it, makes it easier to create the varieties with the favorable fatty acid profiles for the food industry (Duh et al., 1999; Lee et al., 2007; Johnson and Saikia, 2009) and the production of lubricants, including engine and hydraulic oils (Sharma et al., 2005; Erhan et al., 2006) and biodiesel, because the reduced PUFAs result in a lower nitrogen oxides emission and better cold point properties (Tat et al., 2007; Santos et al., 2013). On the other hand, a strong positive correlation between the $\mathrm{OA}$ and $\mathrm{SA}$ means that a caution should be taken, as an increase in the favorable $\mathrm{OA}$ will be followed by an increase in the SFA, which is good for the margarine production (Vollman and Rajcan, 2009), but undesirable health-wise (Crupkin and Zambelli, 2008; Baum et al., 2012). A strong positive relation between the LA and LNA enables the development of cultivars, whose oil can be used in polyol and in other biomaterial industries (Vollman and Rajcan, 2009).

Table 4. Pearson's correlation coefficients ( $r$ ) for fatty acids in 13 early soybean genotypes (2010-12) $(n=156)$

Tablica 4. Pearsonov korelacijski koeficijent (r) za masne kiseline kod 13 ranih genotipova soje (2010. - 2012.) (n $=156$ )

\begin{tabular}{|c|c|c|c|c|}
\hline & SA & OA & LA & LNA \\
\hline PA & $0.07^{\text {ns }}$ & $-0.21^{* *}$ & $0.06^{\text {ns }}$ & $-0.11^{\text {ns }}$ \\
SA & & $0.57^{* *}$ & $-0.77^{* *}$ & $-0.55^{* *}$ \\
OA & & & $-0.91^{* *}$ & $-0.86^{* *}$ \\
LA & & & & $0.74^{* *}$ \\
\hline
\end{tabular}

PA - palmitic acid - palmitinska kiselina; SA - stearic acid - stearinska kiselina; $O A$ - oleic acid - oleinska kiselina; LA - linoleic acid - linolna kiselina; LNA linolenic acid - linolenska kiselina; ${ }^{* *}-\mathrm{p} \leq 0.01$; ${ }^{\mathrm{ns}}$ - insignificant - nije značajno

The dataset including the contents of five predominant fatty acids, the SFA, MUFA, and PUFA and the three ratios (MUFA/PUFA, OA/LA, LA/LNA), was subjected to the PCA to decrease the number of possibly correlated descriptors into a smaller set of mutually orthogonal, uncorrelated principal components explaining the maximum amount of variability. The results are presented in Table 5 and Figure 2. The most significant PCs for the genotypes and the tested traits (Table 5) with the eigenvalues $>1$ are the first four components, explaining $57.84 \%$ of total variability. The loadings for PC 1 , responsible for $33.86 \%$ of variability, indicate that the MUFA/PUFA, MUFA, OA/LA and OA contribute to this axis mostly and are in a positive correlation with it, while the PUFA, LA, and LNA mostly contribute to a negative direction. The PC1 is therefore describing a general trend of correlations resulting from the highest rate of MUFA/ PUFA increase and other variables with the successively lower positive loadings, and the highest rate of PUFA decrease and variables with successively lower negative loadings. The aforementioned variables describing the PC1 are most responsible for the determined phenotypic variability of the tested genotypes and should be taken into consideration while planning the breeding program. The loadings for PC 2, responsible for $10.38 \%$ of variability, show that the PA and SFA have the exerted the greatest impact and are in a positive relation to this axis (Table 5, Fig. 2). PC 3 (7.97\% of the variance) had the highest positive loadings for the LNA and SA and the highest negative one for the LA/LNA and PA, while PC4 $(5.63 \%$ of the variance) had the highest positive loadings for the PA and the highest negative for the LA/ LNA and SA (Table 5). In a study by Shin et al. (2012), PC1 accounted for $28.16 \%$ of the total data variability, described mostly by the $\mathrm{OA}$ and LA, PC2 accounted for $23.16 \%$ of variability, being mostly influenced by the SA and LNA, PC3 accounted for $17.15 \%$ of variability, influenced by the behenic and lignoceric acids, while PC4 accounted for $13.14 \%$ of variability and was mostly under the influence of PA. The differences between studies are expected and are caused by the differences in the genetic makeup and fatty acid profiles of the investigated plant materials. All genotypes, except the OS-L-711, are grouped in the middle of the biplot (Fig. 2), spreading over the first three quadrants, which indicates variability. The genotypes located in the first quadrant (OS-L-513, OS-L-554, OS-L-874, OS-L-875 and OS-L-899) have a higher MUFA/PUFA, MUFA, OA/LA, OA, PA and SFA and a low PUFA, LA, and LNA. Furthermore, the OS-L-899, OS-L-554, OS-L-875 and OS-L-513 are located very near to the SA and the SFA vectors in the first quadrant, and the OS-L-874 is the nearest to the positive PC1 axis. The genotypes located in the second quadrant (OS-L-442, OS-L-453, OS-L-581 and OS-L-821) have a lower MUFA PUFA, MUFA, OA/LA, OA but a high PA, SFA, PUFA, LA and LNA. The OS-L-581 is the nearest to the origin and located on the LNA vector, but the OS-L-453 and OS-L442 are very near as well. The genotypes in the third quadrant (OS-L-526, OS-L-712, and OS-L-877) have a lower MUFA/PUFA, MUFA, OA/LA, OA, PA, SFA but a higher PUFA, LA, and LNA. The OS-L-877 and OS-L-712 are near the origin and both the LA and PUFA vectors, while the OS-L-526 is located somewhat further. The only genotype in the fourth quadrant is the OS-L-711, located very near to the negative $P C 2$ axis, which indicates that it has a high MUFA/PUFA, MUFA, OA/LA, OA, PA, SFA and a low PUFA, LA, and LNA. 
Table 5. The Eigen analysis for $\mathbf{1 3}$ early soybean genotypes and $\mathbf{1 1}$ analysis variables

Tablica 5. Eigen analiza 13 ranih genotipova soje i 11 analiziranih varijabli

\begin{tabular}{|c|c|c|c|c|}
\hline Variable / Varijabla & PC1 & PC2 & PC3 & PC4 \\
\hline PA & -0.01 & 0.49 & -0.37 & 0.20 \\
\hline SA & 0.26 & 0.27 & 0.25 & -0.23 \\
\hline $\mathrm{OA}$ & 0.34 & -0.16 & 0.00 & 0.10 \\
\hline LA & -0.33 & -0.07 & -0.16 & -0.09 \\
\hline LNA & -0.32 & 0.04 & 0.28 & 0.09 \\
\hline SFA & 0.23 & 0.43 & 0.10 & -0.08 \\
\hline MUFA & 0.34 & -0.16 & 0.00 & 0.11 \\
\hline PUFA & -0.35 & -0.04 & -0.04 & -0.04 \\
\hline MUFA/PUFA & 0.35 & -0.09 & 0.02 & 0.07 \\
\hline OA/LA & 0.34 & -0.09 & 0.05 & 0.09 \\
\hline LA/LNA & 0.24 & -0.11 & -0.41 & -0.24 \\
\hline Eigenvalue / Eigen vrijednost & 8.13 & 2.49 & 1.91 & 1.35 \\
\hline Variance (\%) / Varijanca (\%) & 33.86 & 10.38 & 7.97 & 5.63 \\
\hline Cumulative (\%) / Kumulativno (\%) & 33.86 & 44.24 & 52.21 & 57.84 \\
\hline
\end{tabular}

PA - palmitic acid - palmitinska kiselina; SA - stearic acid - stearinska kiselina; OA - oleic acid - oleinska kiselina; LA - linoleic acid - linolna kiselina; LNA - linolenic acid - linolenska kiselina; SFA - saturated fatty acids - zasićene masne kiseline; MUFA - monounsaturated fatty acids - mononezasićene masne kiseline PUFA - polyunsaturated fatty acids - polinezasićene masne kiseline

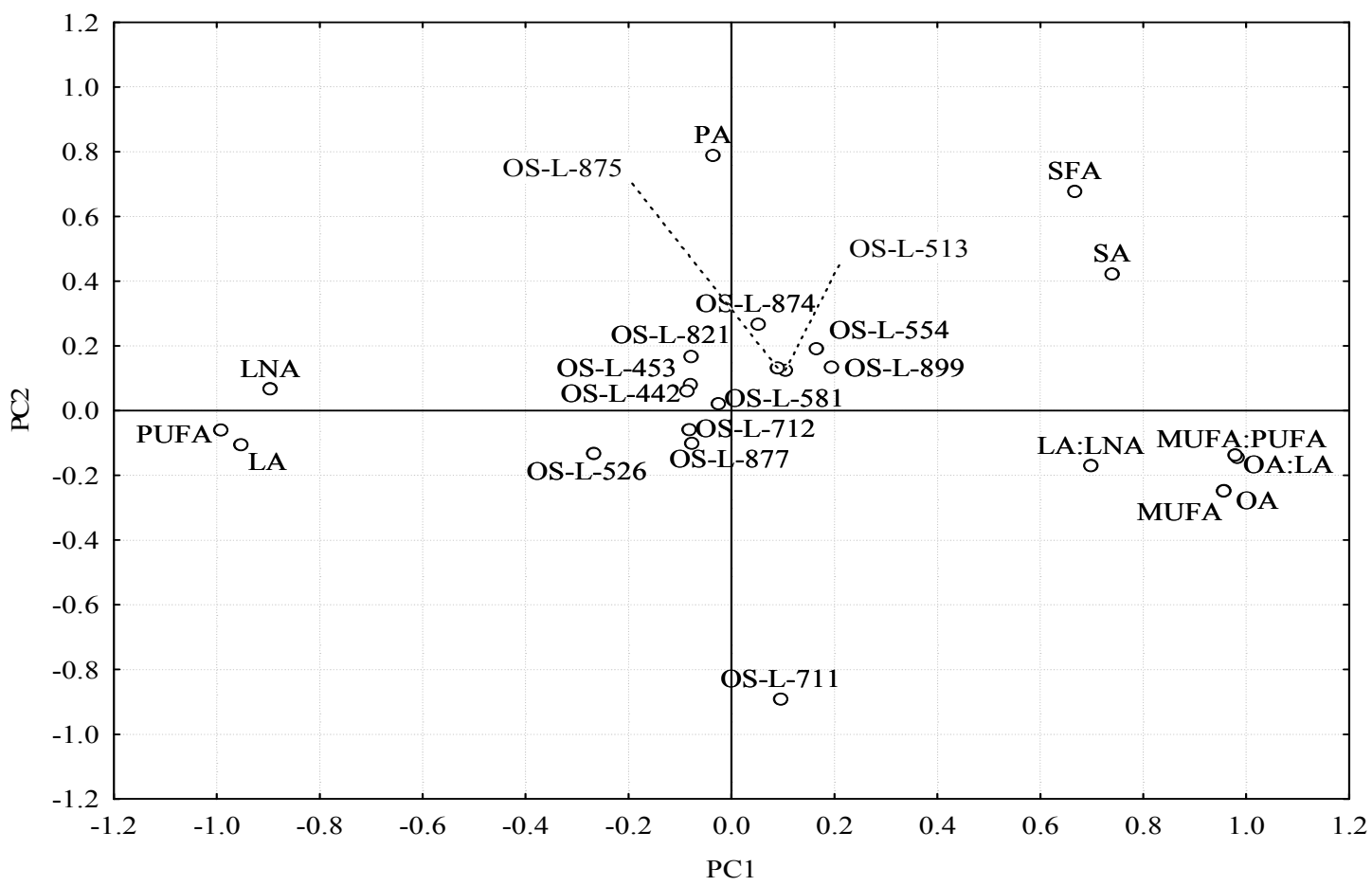

Figure 2. PC1 - PC2 biplot for 13 early soybean genotypes and 11 analyzed variables (palmitic - PA, stearic - SA, oleic - OA, linoleic - LA, linolenic - LNA fatty acid, saturated - SFA, monounsaturated - MUFA, polyunsaturated PUFA fatty acids, MUFA/PUFA, OA/LA, LA/LNA ratios)

Slika 2. PC1 - PC2 biplot za 13 ranih genotipova soje i 11 analiziranih svojstava (palmitinska - PA, stearinska - SA, oleinska - OA, linolna - LA, linolenska - LNA masna kiselina, zasićene - SFA, mononezasićene - MUFA, polinezasićene PUFA masne kiseline, MUFA/PUFA, OA/LA, LA/LNA omjeri) 
The results presented in this study facilitate the choice-making process for the breeding programs depending on the end goal. If the end goal is to create an edible soybean oil, i.e., to increase the oxidative stability without compromising a nutritional quality, the genotypes with the highest content of the $\mathrm{OA}$ and the highest possible OA/LA value but with LA/LNA > 4 (Scollan et al., 2006) should be selected. Although none of the tested genotypes has exhibited the optimal LA/LNA value (Table 2), the genotypes OS-L-711 and OS-L-899 had a higher MUFA content, i.e., a higher MUFA/PUFA value, signifying that they could produce a oil desirable for the engine application and biodiesel production (Sharma et al., 2005; Erhan et al., 2006; Tat et al., 2007; Santos et al., 2013).

\section{CONCLUSION}

The results of this triennial study have determined a significant variability of individual fatty acid (PA, SA, OA, LA, LNA) contents, the contents of SFA, MUFA, and PUFA, as well as an important quality-describing ratios (MUFA/PUFA, OA/LA, LA/LNA) in 13 early soybean genotypes. Genotype, year, and their interaction were the significant sources of variation for all investigated traits where significant environmental effects, as well as GxY, emphasize the need for locationspecific varieties and multi-location testing. Although average contents of all five fatty acids coincided with the average values for commercial soybean, none of the genotypes exhibited properties desirable in edible oil production, i.e., a lower-than-average SFA content, a higher-than-average $\mathrm{OA}$ content, as well as a higher-than-average LNA content. This is further corroborated by higher than optimal LA/LNA values, indicating that there is no sufficient nutritional quality. Furthermore, the average MUFA/PUFA and OA/LA values indicate the tested genotypes would produce oil with a poor oxidative stability and a shorter shelf-life. Nevertheless, the genotype OS-L-711 stands out, as it has the highest MUFA and OA contents, and therefore the highest oxidative stability, so it could be used as a starting point in a breeding program aimed at improving the soybean oil properties for the engine oil and biodiesel production. Besides planning future breeding, the studies which define germplasm in the local genebanks and the susceptibility of important traits to environmental factors are important for improving the diversity through the exchange of materials between different breeding institutions across Europe. This way, the continuously increasing production of soybean in Europe, aiming to rebalance the sources of soybean for the processing industry from an importoriented to a domestic one, would be followed by a continuous and intensive research to create the improved and stable varieties, which would make the European soybean more appealing to the processing industry and render it profitable enough to satisfy the European farmers.

\section{ACKNOWLEDGEMENTS}

This research was carried out in the frame of the Project 073-0730489-0344 that was funded by the Ministry of Science, Education, and Sport of the Republic of Croatia.

\section{REFERENCES}

1. Abdelghany, A. M., Zhang, S., Azam, M., Shaibu, A. S., Feng, Y., Qi, J., ... \& Sun, J. (2020). Natural Variation in fatty acid composition of diverse world soybean germplasms grown in China. Agronomy, 10(1), 24. https://doi.org/10.3390/agronomy10010024

2. Baum, S. J., Kris-Etherton, P. M., Willett, W. C., Lichtenstein, A. H., Rudel, L. L., Maki, K. C., ... \& Block, R. C. (2012). Fatty acids in cardiovascular health and disease: a comprehensive update. Journal of Clinical Lipidology, 6(3), 216-234.

https://doi.org/10.1016/j.jacl.2012.04.077

3. Bellaloui, N., Bruns, H. A., Abbas, H. K., Mengistu, A., Fisher, D. K., \& Reddy, K. N. (2015). Agricultural practices altered soybean seed protein, oil, fatty acids, sugars, and minerals in the Midsouth USA. Frontiers in Plant Science, 6, 31. http://doi.org/10.3389/fpls.2015.00031

4. Brouwer, I. A., Wanders, A. J., \& Katan, M. B. (2010). Effect of animal and industrial trans fatty acids on $\mathrm{HDL}$ and LDL cholesterol levels in humans - A quantitative review. PLoS One, 5, e9434. https://doi.org/10.1371/journal.pone.0009434

5. Bueno, R. D., Borges, L. L., Arruda, K. M. A, Bhering, L. L., Barros, E. G. de, \& Moreira, M. A. (2013). Genetic parameters and genotype $x$ environment interaction for productivity, oil and protein content in soybean. African Journal of Agricultural Research, 8(38), 4853-4859. https://doi.org/10.5897/AJAR2013.6924

6. Chamberlin, K. D., Melouk, H. A., Madden, R., Dillwith, J. W., Bannore, Y., El Rassi, Z., \& Payton, M. (2011). Determining the oleic/linoleic acid ratio in a single peanut seed: A comparison of two methods. Peanut Science, 38(2), 78-84. https://doi.org/10.3146/PS11-3.1

7. Crupkin, M., \& Zambelli, A. (2008). Detrimental impact of trans fats on human health: Stearic acid-rich fats as possible substitutes. Comprehensive Reviews in Food Science and Food Safety, 7(3), 271-279. https://doi.org/10.1111/j.1541-4337.2008.00045.x

8. Dima, D.C. (2016). Soybean demonstration platforms: the bond between breeding, technology and farming in central and Eastern Europe. Agriculture and Agricultural Science Procedia, 10, 10-17. https://doi.org/10.1016/j.aaspro.2016.09.003

9. Duh, P. D., Yen, W. J., \& Yen, G. C. (1999). Oxidative stability of polyunsaturated fatty acids and soybean oil in an aqueous solution with emulsifiers. Journal of the American Oil Chemists' Society, 76(2), 201-204. https://doi.org/10.1007/s11746-999-0218-9

10. Erhan, S. Z., Sharma, B. K., \& Perez, J. M. (2006) Oxidation and low temperature stability of vegetable oil-based lubricants. Industrial Crops and Products, 24(3), 292-299. https://doi.org/10.1016/j.indcrop.2006.06.008 
11. FAOSTAT Database (2020). Available from: http://faostat3.fao.org/home/E [Accessed: March 27, 2020]

12. Fan, S., Li, B., Yu, F., Han, F., Yan, S., Wang, L., \& Sun, J. (2015). Analysis of additive and epistatic quantitative trait loci underlying fatty acid concentrations in soybean seeds across multiple environments. Euphytica, 206(3), 689-700. https://doi.org/10.1007/s10681-015-1491-3

13. Fehr, W. R. (2007). Breeding for modified fatty acid composition in soybean. Crop Science, 47(3), 72-87. https://doi.org/10.2135/cropsci2007.04.0004IPBS

14. Fehr, W. R., Caviness, C. E., Burmood, D. T., \& Pennington, J. S. (1971). Stage of development descriptions for soybeans, Glycine max L. Merrill. Crop Science, 11(6), 929-931. https://doi.org/10.2135/cropsci1971.0011183X001100060051x

15. Ghodrati, G. (2013). Study of genetic variation and broad sense heritability for some qualitative and quantitative traits in soybean (Glycine max L.) genotype. Current Opinion in Agriculture, 2(1), 31-35.

http://doi.org/10.18782/2320-7051.2592

16. Hemingway, J., Eskandari, M., \& Rajcan, I. (2015). Genetic and environmental effects on fatty acid composition in soybeans with potential use in automotive industry. Crop Science, 55(5), 1-11. http://doi.org/10.2135/cropsci2014.06.0425

17. Ivanov, D. S., Lević, J. D., \& Sredanović, S. A. (2010). Fatty acid composition of various soybean products. Food and Feed Research, 37(2), 65-70

18. Johnson, S., \& Saikia, N. (2009). Fatty acids profile of edible oils and fats in India. New Delhi, India: Centre for Science and Environment.

19. Kaiser, H. F. (1960). The application of electronic computers to factor analysis. Educational and Psychological Measurement, 20(1), 141-151. http://doi.org/10.1177/001316446002000116

20. Kumar, V., Rani, A., \& Joshi, O. P. (2004). Fatty acid profile released cultivars of Indian soybean with special reference to identification of high comparatively low linolenic and high oleic acid cultivars. The Indian Journal of Agricultural Sciences, 74(7), 388-391.

21. Kurasch, A. K., Hahn, V., Leiser, W. L., Vollmann, J., Schori, A., Bétrix, C. A., ... \& Sudaric, A. (2017). Identification of mega-environments in Europe and effect of allelic variation at maturity $E$. loci on adaptation of European soybean. Plant, Cell \& Environment, 40(5), 765-778. https://doi.org/10.1111/pce.12896

22. Lee, G. J., Wu, X., Shannon, J. G., Sleper, D. A., \& Nguyen, H. T. (2007). Soybean. In: Kole C, editor. Genome mapping and molecular breeding in plants. Berlin: Springer: 1-3.

23. Mourtzinis, S., Marburger, D., Gaska, J., Diallo, T., Lauer, J., \& Conley, S. (2017). Corn and soybean yield response to tillage, rotation, and nematicide seed treatment. Crop Science, 57(3), 1704-1712. https://doi.org/10.2135/cropsci2016.09.0792

24. Murphy, S. E., Lee, E. A., Woodrow, L., Seguin, P., Kumar, J., Rajcan, I., \& Ablett, G. R. (2009). Association of seed and agronomic traits with isoflavone levels in soybean. Canadian Journal of Plant Science, 89(3), 477484. https://doi.org/10.4141/CJPS08148
25. Pascal, T., \& Rodriguez Cerezo, E. (2015). Markets for non-genetically modified, identity-preserved soybean in the EU. JRC Science and Policy Report. Luxembourg: Publications Office of the European Union. https://doi.org/10.2791/949110

26. Priolli, R. H. G., Carvalho, C. R. L., Bajay, M. M., Pinheiro, J. B., \& Vello, N. A. (2019). Genome analysis to identify SNPs associated with oil content and fatty acid components in soybean. Euphytica, 215, 54. https://doi.org/10.1007/s10681-019-2378-5

27. Rani, A., Kumar., V., Verma, S. K., Shakya, A. K., Hussain, S. M., \& Chauhan, G. S. (2007). Interrelationship between oil content and fatty acid composition in Indian soybean (Glycine max) cultivars. The Indian Journal of Agricultural Sciences, 77(3), 59-62.

https://doi.org/10.31018/jans.v7i2.706

28. Santos, E. M., Piovesan, N. D., de Barros, E. G., \& Moreira, M. A. (2013). Low linolenic soybeans for biodiesel: characteristics, performance and advantages. Fuel, 104, 861-864.

https://doi.org/10.1016/j.fuel.2012.06.014

29. Scollan, N. D., Hocquette, J. F., Nuernberg, K., Dannenberger, D., Richardson, R. I., \& Maloney, A. (2006). Innovations in beef production systems that enhance the nutritional and health value of beef lipids and their relationship with meat quality. Meat Science, 74(1), 17-33. https://doi.org/10.1016/j.meatsci.2006.05.002

30. Sharma, B. K., Adhvaryu, A., Perez, J. M., \& Erhan, S. Z. (2005). Soybean oil based greases: Influence of composition on thermo-oxidative and tribochemical behavior. Journal of Agricultural and Food Chemistry, 53(8), 29612968. https://doi.org/10.1021/jf0486702

31. Shin, E. C., Craft, B. D., Pegg, R. B., Phillips, R. D., \& Eitenmiller, R. R. (2010). Chemometric approach to fatty acid profiles in runner-type peanut cultivars by principal component analysis (PCA). Food Chemistry, 119(3), 1262-1270. https://doi.org/10.1016/j.foodchem.2009.07.058

32. Shin, E. C., Hwang, C. E., Lee, B. W., Kim, H. T., Ko, J. M., Baek, I. Y., Lee, Y. B., Choi, J. S., Cho, E. J., Seo, W. T., \& Cho, K. M. (2012). Chemometric approach to fatty acid profiles in soybean cultivars by Principal Component Analysis (PCA). Preventive Nutrition and Food Science, 17(3), 184-191. https://doi.org/10.3746/pnf.2012.17.3.184

33. Tat, M. E., Wang, P. S., Van Gerpen, J. H., \& Clemente, T. E. (2007). Exhaust emissions from an engine fuelled with biodiesel from high-oleic soybeans. Journal of the American Oil Chemists' Society, 84(9), 865-869. http://doi.org/10.1007/s11746-007-1109-6

34. Vollman, J., \& Rajcan, I. (2009). Oil crop breeding and genetics. In: In Oil Crops (pp. 1-30). Springer, New York, NY. https://doi.org/10.1007/978-0-387-77594-4

35. Williams, C. D., Whitley, B. M., Hoyo, C., Grant, D. J., Iraggi, J. D., Newman, K. A., ... \& Freedland, S. J. (2011). A high ratio of dietary $n-6 / n-3$ polyunsaturated fatty acids is associated with increased risk of prostate cancer. Nutrition Research, 31(1), 1-8. https://doi.org/10.1016/j.nutres.2011.01.002 
36. Wilson, R. F. (2004). Seed composition. In: Boerma, H. R., Specht, J. E., editors. Soybeans: Improvement, production and uses, Ed 3. Madison, Wisconsin, USA: American Society of Agronomy, Crop Science Society of America, Soil Science Society of America, 621-677.

37. Chen, X. (1995). Study on oil content and fatty acid composition of soybean cultivars cultivated in Heliongjiang province in China. Soybean Genetics Newsletter, 22, 99-102. https://doi.org/10.31018/jans.v7i2.706

38. Xue, H. 0, Upchurch, R. G., \& Kwanyuen, P. (2008). Relationships between oleic and linoleic acid content and seed colonization by Cercospora kikuchii and Diaporthe phaseolorum. Plant Disease, 92(7), 1038-1042. https:// doi.org/10.1094/PDIS-92-7-1038

\section{VARIJABILNOST SADRŽAJA MASNIH KISELINA, OKSIDACIJSKA STABILNOST I NUTRITIVNA KAKVOĆA ULJA U ODABRANIM GENOTIPOVIMA SOJE}

\section{SAŽETAK}

Cilj ovoga istraživanja (2010. - 2012.) bio je procijeniti sadržaj masnih kiselina (palmitinska - PA, stearinska - SA, oleinska - OA, linolna - LA, linolenska - LNA, zasićene masne kiseline - SFA, mononezasićene masne kiseline - MUFA, polinezasićene masne kiseline - PUFA), oksidacijsku stabilnost (MUFA/PUFA, OA/LA) i nutritivnu kakvoću (LA/LNA) ulja 13 ranih genotipova soje nastalih u Poljoprivrednome institutu Osijek, Hrvatska. Analizom varijance utvrđeno je postojanje varijabilnosti za sva testirana svojstva, pri čemu su genotip (G), godina (Y) i GxY značajni izvori varijacije. Najznačajnije pozitivne korelacije su utvrđene između SA i OA, SA i LNA i LA i LNA, a najznačajnije negativne između OA i LA i OA i LNA. Analizom glavnih sastavnica utvrđeno je kako postoje četiri primarne osi sa svojstvenim vrijednostima $>1$, koje zajedno objašnjavaju 57,84\% varijabilnosti ukupnih podataka. Prva primarna os (PC1) najviše je u pozitivnome smjeru vezana za svojstva MUFA/PUFA, MUFA, OA/OALA i OA, a u negativnome smjeru za PUFA, LA i LNA. Ovi rezultati bit će od pomoći pri planiranju budućih oplemenjivačkih programa usmjerenih $k$ prilagodbi sastava $i$ sadržaja masnih kiselina prema potrebama prerađivačke industrije i krajnjih korisnika.

Ključne riječi: masne kiseline, nutritivna kakvoća, ulje, oksidacijska stabilnost, soja, PCA

(Received on June 24, 2020; accepted on November 10, 2020 - Primljeno 24. lipnja 2020.; prihvaćeno 10. studenoga 2020.) 